\title{
Bacteriological Identification of Selected Pathogens in Infected Primary and Young Permanent Teeth Associated with Clinical Symptoms
}

\author{
Teuta Kutllovci', Snezana Iljovska ${ }^{2}$, Agim Begzati1, Mira Jankulovska², \\ Mirjana Popovska ${ }^{2}$, Aida Rexhepi ${ }^{1}$, Blerta Latifi-Xhemajli1 \\ ${ }^{1}$ Department of Pediatric Dentistry, University Dental Clinic of Kosova, Prishtina, Kosovo \\ ${ }^{2}$ Department of Pediatric Dentistry, Ss. Cyril and Methodius University in Skopje, Skopje, Macedonia \\ Email: teutakutllovci62@hotmail.com
}

Received 27 March 2015; accepted 30 May 2015; published 2 June 2015

Copyright (C) 2015 by authors and Scientific Research Publishing Inc.

This work is licensed under the Creative Commons Attribution International License (CC BY).

http://creativecommons.org/licenses/by/4.0/

(c) (i) Open Access

\section{Abstract}

Background: The common cause of dental infections is necrosis of the pulp of a tooth, which is followed by bacterial invasion through the pulp chamber into the deeper tissues. The bacterial infections are caused by host indigenous bacteria primarily aerobic gram positive cocci, anaerobic gram negative and gram negative rods. The aim of this study is to identify the presence of different cultivating microorganisms which cause dental infections in primary and young permanent teeth manifested by as abscesses and apical parodontitis. Material and Methods: Seventy kids ages 5 - 15 years ( 36 females, 34 males) were studied prospectively (I assume this) at the University Dental Clincal Center of Kosovo, Department of Pediatric Dentistry in cooperation with Microbiological Department of Faculty of Medicine. All patients who had clinical, and radiological confirmation of thier dental infections, followed by extraction of their teeth. Once the tooth was extracted blood and pus sample from the empty alveoli were cultured. The analysis of the sample for bacteria identification was done using the automated system VITEK 2 cards (Biomeriux, France). Results: Of 70 children's with deciduous $73.5 \%$ of them had acute infection and $26.5 \%$ chronic infection. On the other hand $75 \%$ of children with permanent dentitions had chronic and $25 \%$ acute infection. In acute infections the most common aerobic bacteria was Streptococcus group with $\mathbf{4 7 \%}$ (Streptococcus mitis and oralis) followed by the Actonomyces group (Actinomyces mayeri and Actinomyces odontoliticus) and anaerobic bacteria in $34 \%$. In chronic infections streptococcus group was the prevalent aerobic group and in anaerobic infection Actinomyces mayeri and Actinomyces naeslundi was the most representative aerobes in $21 \%$ of samples. Conclusion: The dental infections in pediatric population (5 - 15 years old) are polymicrobial predominantly anaerobic bacte- 
ria over aerobic. This study paves the way for preventives measures that need to me implemented in this group of children.

\author{
Keywords \\ Dental Infections, Children, Aerobic Bacteria, Anaerobic Bacteria, Acute Infection, Chronic \\ Infection
}

\title{
1. Introduction
}

Oral and maxillofacial infections are common health problems worldwide. More than 500 bacterial species are known to constitute normal oral microbiota [1]. Dentalcaries, on the other hand, is considered to be endogenous bacterial disease, caused by oral cavity bacterial flora with have latent pathogenic potential. The disease is a result of creatiton of favorable conditions where by the resistance of the host (the tooth) is reduced and the specific bacterial species multiply, leading to expression in cariogenic types. If caries is not treated, complications occur with repercussions to pulp-periodontal complex [2].

A number of studies have reported on the microbial composition of necrotic dental pulps, that is in infected root canal, and have indicated the presence of facultative anaerobic bacteria, which are usually present in oral envoirment.Some studies have also shown that obligate anaerobes predominated in infected root canals of teeth and made as up as much as $90 \%$ or more of the microbiota [3] [4].

Pulp diseases and periodontal tissues diseases depend of anatomical, physiological and histological characteristics. The growth and development of orofacial system as a whole, the development and maturation processes of dento-alveolar tissue and involutive processes in primary and young permanent teeth are of great importance for the genesis and development of the dental infections in children [5]. Pulp of the tooth primary is infected and becomes necrotic of its own oral microflora. Conditions in pulpal low to settle inside of if mixed, mostly anaerobic flora.

This polymicrobial community which is part of the root canal has several biological and pathogenic characteristics as antigenicity, mitogenic characteristics, chemotaxis, histolysis with enzymes and activation of host cells. Microbial invaders in root canal themselves can progress or their products can be spread to the periapical tissue. As response to them, the host activates its defense mechanism which is composed of several type of cells, intercellular substances, antibodies and effectors molecules [6]-[8].

Etiology and pathogenesis of dental infections in children are the same in the primary (deciduous) teeth and in the permanent teeth, but they differ only by the course of the process because of the specifics in the anatomical and physiological conditions of the jaws and in the organism of the child as a whole, which is still in a phase development. Therefore, according to Caufield et al. [3], the pathogenesis of dentogenic infections depends on variety of the roots from primary (deciduous) teeth is their formation and absorption, then from the location and closeness of the beginnings of the permanent teeth and their follicles which are well vascularized. The expansion of the pathological process is also affected by the anatomical structure of procesus alveolaris, which is very thin in children and the spongious part of bone is rarer. The predisposition of the child organism to inflammation of bone and bone marrow and to the soft tissues is with special importance. According to some authors, dentin canals of primary (deciduous) teeth are more wider than those in permanent teeth, which contributes to faster spread of caries [9]-[11]. Seow [12] has established that these canals are wider in peripheral dentin at primary teeth than at permanent teeth where the dentin layers are closer to the pulp were almost the same width.

A spredominant pathology which is a consequence of chronic dentogenic infections, are considered those teeth that were with chronic apical paradontitis with fistula, then parulis which is subgingival localized abscess in alveolar bone and who is connected with chronic periapical process of primary tooth through fistulising canal. And the residual roots of primary teeth with apical processes are considered as a relevant factor responsible for the occurrence of dentogenic infections [13].

For the permanent teeth, on the other hand are chronic apical paradontitis with fistula; fractured teeth with fistula (as a consequence of dental caries or dental trauma); apical paradontitis verified with radiographs; residual gangrenous teeth with periapical processes and fistula;and secondary caries with periapical processes as a result of the failed treatment of dental caries [14]. 
The aim of this prospective study was to 1) Investigate the bacterial strains of aerobic and anaerobic bacteria in samples taken from alveoli of freshly extracted teeth of deciduous and permanent dentition with acute and chronic dental infections, and 2) To determine the species of each isolated group of identified bacteria from aerobic and anaerobic microorganisms.

\section{Materials and Methods}

Seventy kids aged 5 - 15 years (36 females, 34 males) were studied prospectively at the University Dental Clincal Center of Kosovo, Department of Pediatric Dentistry in cooperation with Microbiologic Department of Faculty of Medicine. All patients who had clinical and radiological confirmation of their dental infections, followed by extraction of their teeth. Once the tooth was extracted blood and pus sample from the empty alveoli were cultured. The analysis of the sample for bacteria identification was done using the automated system VITEK 2 cards (Biomeriux, France) for the identification of gram positive (ID-GP cards) and gram negative (ID-GN cards).The bacterial suspension through the special pipe transferred prepared blood suspension up to card. Through this pipe, material is transferred from suspension up to card. Cards are also recorded in automated VITEK system. After registration cards are placed in VITEK apparatus for identification of gram—positive bacterium, 24 hour mean.

They were in good general health and had not been treated for any other illness. This research study was approved by the Human Ethic Commitee of the University Dental Clinical Center of Kosova.

\subsection{Clinical and Sampling Procedures}

Children were seen in the University Dental Clincal Center of Kosov with the clinical symptoms of dental abscesses of the acute forms and teeth with acute intraoral fistulas. After clinical examinations and radiologic verification, and diagnosing them as teeth with dental infections, it is decided to extract these teeth. Parents were explained about the importance of extraction of these teeth and about the inability to keep them because of inability to salvage them. Parents agreed to the procedure in writing.

Each child was prepared for the extraction, and adequate anesthesia is given. In the cases when giving anesthesia was not possible, the local anesthesia of the oral mucosa around the tooth was done, and the tooth was extracted (this happened with the deciduous teeth), especially molars with the resorption level greater than $1 / 3$ of the length of the root.

Permanent teeth that were extracted and used as samples were with large damage surface of unable to be treated conservatively.

After isolating the working area and giving the anesthesia, the infected tooth was extracted, immediately after the extraction the blood and pus was aspirated from the empty alveoli and around $1 \mathrm{ml}$ of material was aspirated. This was sufficient for microbiological material. A sterile syringe without the needle was passed through alveolar mucosa into the abscess, from which the content was withdrawn. The obtained material was closed, the number of the sample was noted, and it was sent to the microbiological laboratory. Sampling was again performed as in the case of patient with periapical lesions. All collected samples (aspiration and per apical pathological tissues )were taken immediately after extraction of the tooth and cultured directly in Columbia agar $+5 \%$ sheep blood agar plates (Biomeriux, Lyon, France).

Removal with excision of the periapical lesion was decided in the case of teeth could not be preserved due to resorption of over one third of the root. Such extraction was also decided in the case of non-restorable teeth and in cases where the patient did not accept any other type of treatment.

\subsection{Microbiological Isolation and Species Determination}

Pus and blood samples were aspirated after fresh extracted alveoli and marked the syringe with the number and immediately send to the microbiologic laboratory. After the planting in blood agar, identification was done with special Vitek 2 card for bacterial identification the bacterial pathogens for which they are intended those files. Identification of bacteria strains was done by Vitek 2 GP cards and Vitk 2 GN cards (BioMeriux, France).With the Vitek 2 GP ID and Vitek 2 GN ID rapid and accurate identification of broad range of clinically significant Gram positive and Gram negative pathogens were cultivated in samples.

Data analysis was done with Statistica 7.1 statistical program, where are using these methods:

-Series Formed in the parameters of examined are shown in numbers, which are based on the number and percentage of aerobic and anaerobic bacteria isolated in decidous and permanent teeth, and which have been 
worked with Descriptive Statistics expressed as count and percent.

\section{Results}

A total of 202 bacterial strains were isolated from 70 patients, 122 aerobic specie; $60.5 \%$, and $38 \%$ anaerobic specie, $2 \%$ was Candida and $0.5 \%$ was undifferentiated (Figure 1)

All samples are divided in 3 groups and each group is studied with 2 sub-groups (6 groups all together). The first group were patients with acute and chronic infections, in the second group are studied patients with deciduous and permanent dentition and in the third study research consist in analyzes from blood and pus samples taken from each group.

Of 70 children, 34 (48.5\%) of them had dental infection in deciduous teeth and 36 (51.5\%) in permanent teeth. While the acute infections dominated in deciduous dentition, in permanent dentition we have the preponderance of chronic apical infections (Table 1 and Figure 2).

In all samples with acute infections, Streptococcus group, mitis and oralis were present in 30\%, Str. pyogenes gr. A in $12.9 \%$, and Str.sanguinis in $10 \%$. The other bacteria that are isolated also in streptococcus group are presented in 2.9\%.Staphylococcus epidermidis and Kocuria Kristinae in 1.4\% (Table 2 and Figure 3).

Of anaerobic bacteria in acute infections the most prevalent bacteria was Actynomyces group Actinomyces mayeri in $18.6 \%$, Actinomyces odontoliticus in $8.6 \%$ and Actinomyces naeslundi in $7.1 \%$. Lactobacillus gasseri was isolated in $4.2 \%$ and Prevotella, Veilonella and Clostridium Clostridiformis was isolated in $2.9 \%$.The other bacteria were present in 1.4\% present in samples (Table 3 and Figure 4).

In chronic infections we have higher percentage of Streptococcus mitis (44.4\%) and oralis (41.6\%) and Streptococcus sanguinis had the same value as in acute infections (10\%).Other aerobes isolated on chronic infections are also from streptococcus group, Streptococcus sanguinis gr " $\mathrm{A}$ " and Kocuria rosea with Granulicatela adiacens both in 5.7\%. Staphilococus epidermidis, Leuconostoc m. spp. cremoris, Erisypela rhusiopathiae and Serratia marescens are presented only in 2.9\% (Table 4 and Figure 5). In patients with chronic infections

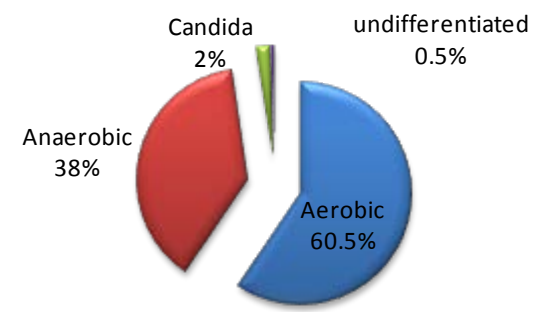

Figure 1. Bacteria isolates from samples.

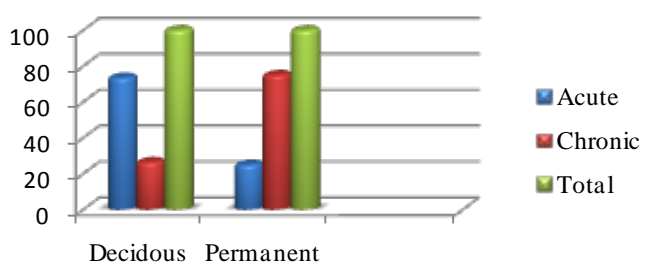

Figure 2. Children with acute and chronic dental infections.

Table 1. Children with acute and chronic dental infections.

\begin{tabular}{ccccccc}
\hline & \multicolumn{5}{c}{ Dentition } & \\
\hline \multirow{2}{*}{ Infection } & Decidous & Percent & Permanent & Percent & Total & Percent \\
\cline { 2 - 7 } & $\mathrm{N}$ & $\%$ & $\mathrm{~N}$ & $\%$ & $\mathrm{~N}$ & $\%$ \\
\hline Acute & 25 & 73.5 & 9 & 25 & 34 & 48.5 \\
Chronic & 9 & 26.5 & 27 & 75.0 & 36 & 51.5 \\
Total & 34 & 100 & 36 & 100 & 70 & 100 \\
\hline
\end{tabular}


Table 2. Bacteria aerobic isolated from acute abscesses in deciduous and permanent dentitions.

\begin{tabular}{|c|c|c|c|c|c|c|}
\hline \multirow{2}{*}{$\begin{array}{l}\text { Bacterialaerobic } \\
\text { species }\end{array}$} & \multicolumn{2}{|c|}{ Decidous dentition } & \multicolumn{2}{|c|}{ Permanent dentition } & \multicolumn{2}{|c|}{ Total } \\
\hline & $\begin{array}{l}\text { No.of specimens/ } \\
\text { no.of sample }\end{array}$ & $\begin{array}{l}\text { Percent } \\
\%\end{array}$ & $\begin{array}{l}\text { No.of specimens/ } \\
\text { no. ofsample }\end{array}$ & Percent \% & $\begin{array}{l}\text { No.of specimens/ } \\
\text { no. of sample }\end{array}$ & Percent \% \\
\hline Str.mitis & $16 / 34$ & 47 & $5 / 36$ & 13.9 & $21 / 70$ & 30 \\
\hline Str.oralis & $16 / 34$ & 47 & $5 / 36$ & 13.9 & $21 / 70$ & 30 \\
\hline Str.sanguinis & $5 / 34$ & 14.7 & $2 / 36$ & 5.6 & $7 / 70$ & $10 \%$ \\
\hline Str.pyogenes gr"A" & $5 / 34$ & 14.7 & $4 / 36$ & 11.1 & $9 / 70$ & 12.9 \\
\hline Str.salivarius & $2 / 34$ & 5.9 & I & l & $2 / 70$ & 2.9 \\
\hline Str.anginosus & $1 / 34$ & 3 & $1 / 36$ & 2.8 & $2 / 70$ & 2.9 \\
\hline Str.Gordonii & $1 / 34$ & 3 & l & l & $1 / 70$ & 1.4 \\
\hline Str.pneumoniae & $1 / 34$ & 3 & I & I & $1 / 70$ & 1,4 \\
\hline Str.ovis & $1 / 34$ & 3 & I & l & $1 / 70$ & 1.4 \\
\hline Str.parasanguinis & $1 / 34$ & 3 & / & I & $1 / 70$ & 1.4 \\
\hline Stafiloko.epidermidis & $1 / 34$ & 3 & I & l & $1 / 70$ & 1.4 \\
\hline Kocuria kristinae & l & l & $1 / 36$ & 2.8 & $1 / 70$ & 1.4 \\
\hline
\end{tabular}

Table 3. Bacteria anaerobic isolated from acute abscesses in deciduous and permanent dentitions.

\begin{tabular}{|c|c|c|c|c|c|c|}
\hline \multirow{2}{*}{$\begin{array}{c}\text { Bacterial anaerobic } \\
\text { species }\end{array}$} & \multicolumn{2}{|c|}{ Decidous dentition } & \multicolumn{2}{|c|}{ Permanent dentition } & \multicolumn{2}{|c|}{ Total } \\
\hline & $\begin{array}{c}\text { No. of specimens/ } \\
\text { no.of sample }\end{array}$ & Percent\% & $\begin{array}{c}\text { No. of specimens/ } \\
\text { no.of sample }\end{array}$ & Percent\% & $\begin{array}{c}\text { No. of specimens/ } \\
\text { no.of sample }\end{array}$ & $\begin{array}{c}\text { Percent } \\
\%\end{array}$ \\
\hline Actynomyces mayeri & $8 / 34$ & 23.5 & $5 / 36$ & $13.9 \%$ & $13 / 70$ & $18.6 \%$ \\
\hline Actynom. naeslundi & $3 / 34$ & 8.8 & $2 / 36$ & 5.5 & $5 / 70$ & 7.1 \\
\hline Actynom.odontolit. & $5 / 34$ & 14.7 & $1 / 36$ & 2.8 & $6 / 70$ & 8.6 \\
\hline Clostridium clostrid. & $2 / 34$ & 5.9 & / & I & $2 / 70$ & 2.9 \\
\hline Clostridium hystolit. & $1 / 34$ & 3 & / & / & $1 / 70$ & 1.4 \\
\hline Clostridium novyi & $1 / 34$ & 3 & / & / & $1 / 70$ & 1.4 \\
\hline Clostridium limosum & $1 / 34$ & 3 & / & / & $1 / 70$ & 1.4 \\
\hline Veilonella spp. & $2 / 34$ & 5.9 & l & l & $2 / 70$ & 2.9 \\
\hline Atopobium vaginae & $1 / 34$ & 3 & $1 / 36$ & I & $2 / 70$ & 2.9 \\
\hline Lactobacillus & $1 / 34$ & 3 & $1 / 36$ & 2.8 & $2 / 70$ & 2.9 \\
\hline Lactobacillus gasseri & $3 / 34$ & 8.8 & / & / & $3 / 70$ & 4.2 \\
\hline Prevotella & I & I & $1 / 36$ & 2.8 & $1 / 70$ & 2.9 \\
\hline
\end{tabular}

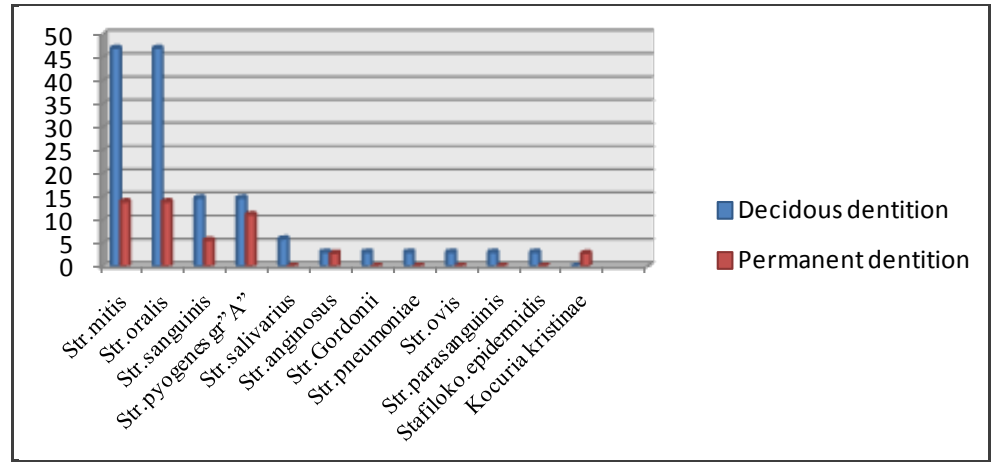

Figure 3. Bacteria aerobic isolated from acute abscesses in deciduous and permanent dentitions. 


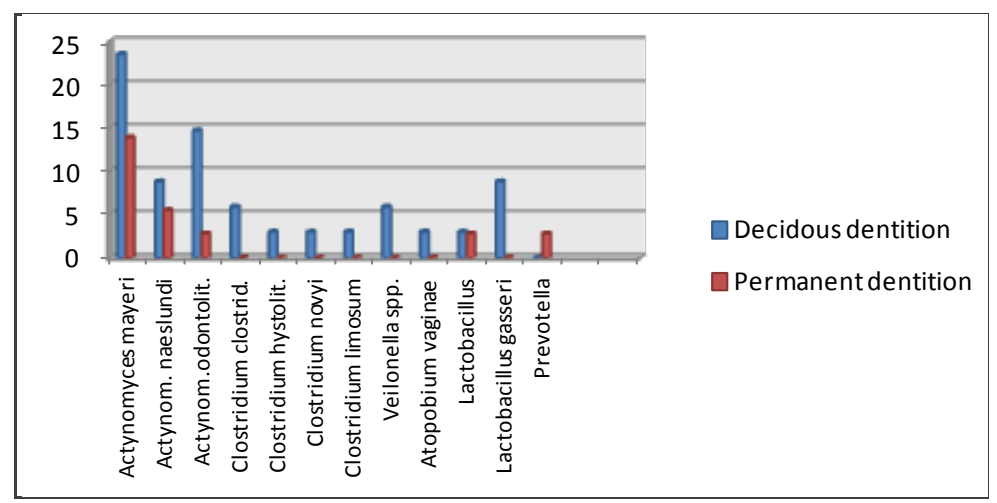

Figure 4. Bacteria anaerobic isolated from acute abscesses in deciduous and permanent dentitions.

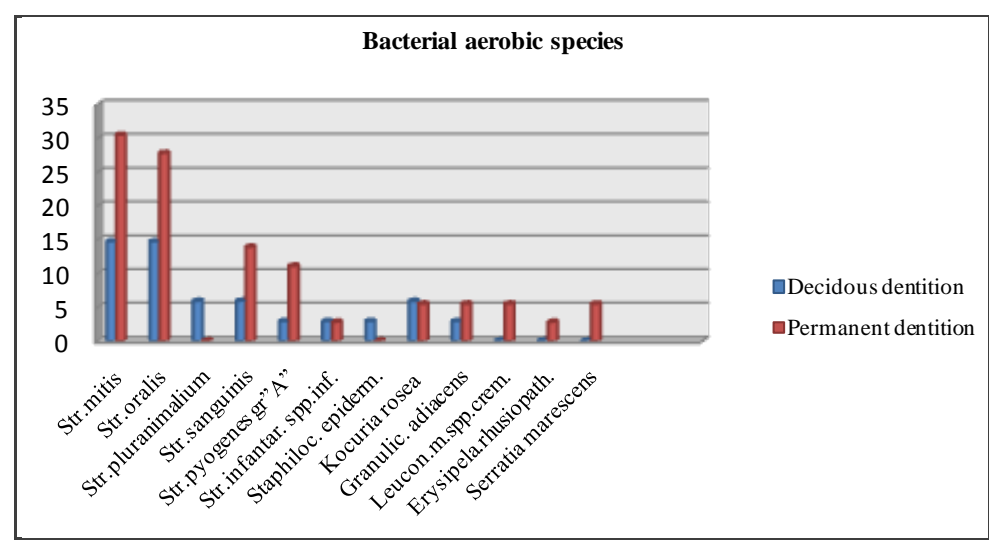

Figure 5. Bacteria aerobic species isolated from chronic abscesses in deciduous and permanent dentitions.

Table 4. Aerobic species isolated from chronic abscesses in deciduous and permanent dentitions.

\begin{tabular}{ccccccc}
\hline & \multicolumn{2}{c}{ Decidous dentition } & \multicolumn{2}{c}{ Permanent dentition } & \multicolumn{2}{c}{ Total } \\
\cline { 2 - 7 } Bacterial aerobic species & $\begin{array}{c}\text { No.of specimens/ } \\
\text { no.of sample }\end{array}$ & Percent (\%) & $\begin{array}{c}\text { No.of specimens/ } \\
\text { no.of sample }\end{array}$ & Percent (\%) & $\begin{array}{c}\text { No.of specimens/ } \\
\text { no.of sample }\end{array}$ & Percent(\%) \\
\hline Str.mitis & $5 / 34$ & 14.7 & $11 / 36$ & 30.5 & $16 / 70$ & 44.4 \\
Str.oralis & $5 / 34$ & 14.7 & $10 / 36$ & 27.8 & $15 / 70$ & 41.6 \\
Str.pluranimalium & $2 / 34$ & 5.9 & $/$ & $/$ & $2 / 70$ & 2.9 \\
Str.sanguinis & $2 / 34$ & 5.9 & $5 / 36$ & 13.9 & $7 / 70$ & 10.0 \\
Str.pyogenes gr“A” & $1 / 34$ & 2.9 & $4 / 36$ & 11.1 & $5 / 70$ & 7.1 \\
Str.infantar. spp. inf. & $1 / 34$ & 2.9 & $1 / 36$ & 2.8 & $2 / 70$ & 2.9 \\
Staphiloc. epiderm. & $1 / 34$ & 2.9 & $/$ & $/$ & $1 / 70$ & 2.9 \\
Kocuria rosea & $2 / 34$ & 5.9 & $2 / 36$ & 5.5 & $4 / 70$ & 5.7 \\
Granulic. Adiacens & $2 / 34$ & 2.9 & $2 / 36$ & 5.5 & $4 / 70$ & 5.7 \\
Leucon.m.spp.crem. & $/$ & $/$ & $2 / 36$ & 5.5 & $2 / 70$ & 2.9 \\
Erysipela.rhusiopath. & $/$ & $/$ & $1 / 36$ & 2.8 & $1 / 70$ & 2.9 \\
Serratia marescens & $/$ & $/$ & 5.5 & $2 / 70$ & 2.9 \\
\hline
\end{tabular}


Actinomyces mayeri was present in $11.4 \%$ and Actynomyces naeslundi in $10.0 \%$, while the Anaerococcus prevoti was present in $7.1 \%$ and Lactobacillus gasseri in 5.7\%. The other bacteria, Lactobacillus and Biffidobacterium spp. was in 2.9\%. Clostridium group and Finegoldia magna were present with 1.4\% (Table 5 and Figure 6).

\section{Discussion}

In our study, we have demonstrated that the dental infections in pediatric population (5 - 15 years old) are polymicrobial predominantly anaerobic bacteria over aerobic. This study paves the way for preventives measures that need to me implemented in this group of children. Epidemiological features of dental infections were the object of research by authors from the world's leading research institutes. Caste [14] within period of 1976-79 year investigated bacteriology and treatment of 61 patients with an average age of 15 - 25 years. While Hunt [15] and collaborators studied the microbiological and epidemiological characteristics at a state hospital in the United States, as well as a simple predominance of male (52\%), Haimdahl [16] reported management of microbiological data for 58\% of patients. Batty (in 1958) [17] isolated Actinomyces odontoliticus in caries samples from patients with advanced caries. Dodson [18] [19] gave demographic data for 113children, finding the existence of a high level of infection in female children (59\%) compared with the male (41\%) and the average age was 4.5 years.

Table 5. Anaerobic species isolated from chronic abscesses in deciduous and permanent dentitions.

\begin{tabular}{|c|c|c|c|c|c|c|}
\hline \multirow{2}{*}{ Bacterial anaerobic species } & \multicolumn{2}{|c|}{ Decidous dentition } & \multicolumn{2}{|c|}{ Permanent dentition } & \multicolumn{2}{|c|}{ Total } \\
\hline & $\begin{array}{c}\text { No. of specimens/ } \\
\text { no.of sample }\end{array}$ & Percent (\%) & $\begin{array}{l}\text { No. of specimens/ } \\
\text { no.of sample }\end{array}$ & Percent (\%) & $\begin{array}{l}\text { No. of specimens/ } \\
\text { no.of sample }\end{array}$ & Percent (\%) \\
\hline Actynomyces mayeri & l & / & $8 / 36$ & $22.2 \%$ & $8 / 70$ & $11.4 \%$ \\
\hline Actynomyces naeslundi & $2 / 34$ & $5.9 \%$ & $5 / 36$ & $13.9 \%$ & $7 / 70$ & $10.0 \%$ \\
\hline Actinomyces odontoliticus & l & / & $1 / 36$ & $2.8 \%$ & $1 / 70$ & $1.4 \%$ \\
\hline Clostridium bifermentans & $1 / 34$ & $2.9 \%$ & / & / & $1 / 70$ & $1.4 \%$ \\
\hline Clostridium clostridiformis & $1 / 34$ & $2.9 \%$ & l & l & $1 / 70$ & $1.4 \%$ \\
\hline Clostridium novyi & / & / & $1 / 36$ & $2.8 \%$ & $1 / 70$ & $1.4 \%$ \\
\hline Lactobacillus & $1 / 34$ & $2.9 \%$ & $1 / 36$ & $2.8 \%$ & $2 / 70$ & $2.9 \%$ \\
\hline Anaerococus prevoti & $3 / 34$ & $8.8 \%$ & 2/36 & $5.5 \%$ & $5 / 70$ & $7.1 \%$ \\
\hline Peptostrep.asaccharoly. & l & l & $1 / 36$ & $2.8 \%$ & $1 / 70$ & $1.4 \%$ \\
\hline Lactobacillus gasseri & l & l & $4 / 36$ & $11.1 \%$ & $4 / 70$ & $5.7 \%$ \\
\hline Finegoldia magna & / & l & $1 / 36$ & $2.8 \%$ & $1 / 70$ & $1.4 \%$ \\
\hline Bifidobacterium spp. & $1 / 34$ & $2.9 \%$ & $1 / 36$ & $2.8 \%$ & $2 / 70$ & $2.9 \%$ \\
\hline
\end{tabular}

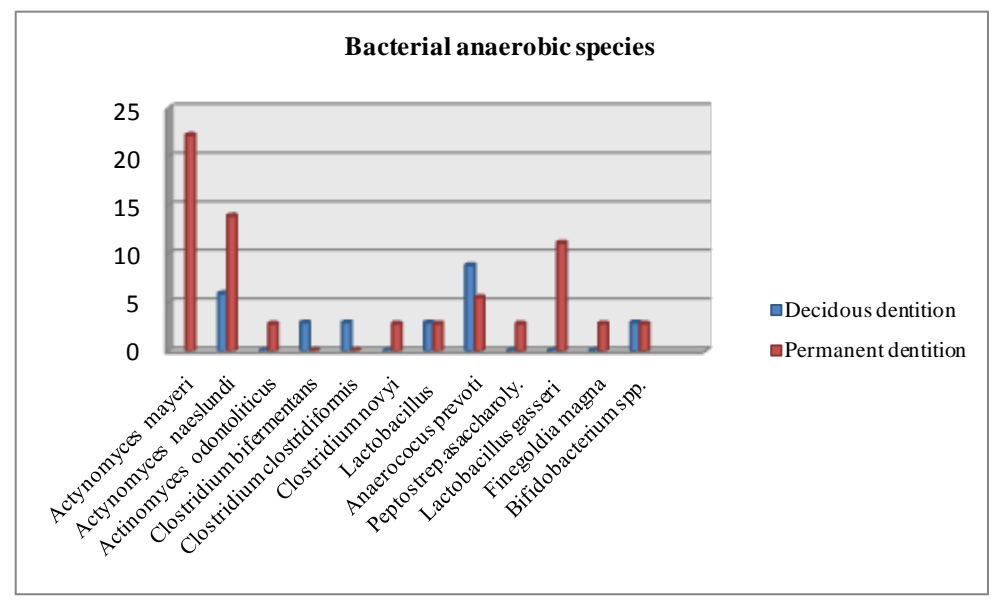

Figure 6. Anaerobic species isolated from chronic abscesses in deciduous and permanent dentitions. 
More evidence suggests that apical periodontitis is a disease in which biofilm has leading role in the etiology. In situ researches which are made using optical and /or electronic microscope allow be identified bacteria that colonize the root canals of primary infected teeth or in the teeth with persistent infection where bacteria are in the form of biofilms that cover root canal walls [12] [13] [20]-[23]. Apical ramifications, lateral canals and isthmuses that connect the mainroot canals are shown to contain bacterial cells that are often formed biofilms. [14] [15] [24] Biofilms which are found on the apical surface of roots (extra radicular biofilms) is assumed to have etiological role in apical period ontitis which occurs after treatment of the roots [16] [17].

Very few studies have been made for the microbiological flora of the root canals at primary teeth. In researches of Pazelli [24] made in a total of 20 primary teeth with necrotic pulp in the region of furcation in the teeth and/or periapical regions, anaerobic microorganisms were selected in $100 \%$ of the samples, black-pigmented bacilli in 30\%,aerobic microorganisms in 60\%, streptococci $85 \%$, Gram-negative aerobicrods $15 \%$ and staphylococci were not quantified. Streptococcus mutans was found in 6 root canals (30\%), from which 5 canals were with Streptococcus mutans and 1 canal was with Streptococcus mutans and Streptococcus sobrinus. It was then concluded that in the root canals of deciduous teeth with necrotic pulp and periapical lesions, the infection is polymicrobial with predominance of anaerobic microorganisms.

Until 1970 the most common bacterial group isolated with culture from root canals of permanent teeth was Streptococcus viridians (alpha haemolytic streptococcus).Then, with the development of strictly anaerobic cultural techniques, the concept of endodontic infections has changed since anaerobic microorganisms, which were rarely isolated, were identified as predominant endodontic microorganisms in the flora of permanent teeth with necrotic pulp and periapical lesions [12] [16].

Studies by William [25] from 1970 have pointed out that the most common bacterial group isolated with cultivation from root canals of permanent teeth were Streptococcus viridians (alpha haemolytic streptococcus).

Oguntebi et al. also find that Streptococcus mitis are the predominant bacteria in isolate samples taken in periapical abscesses [26].

Sakaguchi [25] et al. believe that the development of anaerobic cultural techniques and the concept of endodontic infections are changed, and because of that, the anaerobic microorganisms which were rarely isolated microorganisms were predominant microorganisms in the flora at permanent teeth with necrotic pulp and periapical lesions. Very few studies have been performed on the microbiological flora in the root canals from primary teeth, but should be noted that the presence of Streptococcus mutans in the root canals of primary teeth was not found previoulsy.

Hegde and Pallavi also isolate Streptococcus mutans in 100\% of sample [27]. According to Brook from of aspiration in 12 children with per apical abscesses he isolated $67 \%$ anaerobes and the others were aerobic and facultative aerobic [28].

Marsh and Largent [29] found that the most frequent microorganisms in the root canals of deciduous teeth with necrotic pulp and periapical lesions were Streptococcus salivarius. Da Silva (2010) [30] found polymicrobial infections in primary teeth, mostly anaerobic microorganisms. J. F. Siqueira (2003) [31] isolated Bacteroidetes, Firmicutes, Actinobacteria, fusobacteria and Proteo bacteria (with DNA and Spirochaetes and Deferribacteres) and Pazelli et al. (2009) [24] detected anaerobic microorganisms and types of streptococci in root canals with necrotic pulp at primary teeth. According to Gill. I, Skali C (2009) [32] the most common pathogenic actors of these infections in permanent teeth were Bacteroides, Fusobacteria, peptococci, peptostreptococci and streptococcus viridans group while Léa Assed Bezerra (2010) [30] isolated aerobic MO, streptococci, Gramnegative aerobic rods and Streptococcus mutans and Streptococcus sobrinus. Ashok [33] in their investigations revealed the presence of Gram positive cocci(Peptococcus and Peptostreptococcus), Grampositive bacilli (Lactobacillus, Bifidobacterium, Propionobacterium and Eubacterium), Gram negativecocci (Veillonella parvula) and aerobic bacteria, ferences staphylococci, streptococci, E. coli, K. pneumonia, P. aeruginosa and Candida albicans.

Because of the low level of dental education and the lack of a preventive system inclusive of children in all school levels, appearance of dental infections is relatively frequent pathology in our young population. So, prevention of caries and its complications will greatly reduce the appearance of dental infections.

\section{Conclusion}

Our study in 70 children ages 5 - 15 years old has demonstrated that the dental infections in pediatric population 
are polymicrobial predominantly anaerobic bacteria over aerobic. This study paves the way for preventives measures that need to me implemented in this group of children.

\section{References}

[1] Ehrlich, G.D., Hu, F.Z., Shen, K., Stoodley, P. and Post, J.C. (2005) Bacterial Plurality as a General Mechanism Driving Persistance in Chronic Infections. Clinical Orthopaedics and Related Research, 437, 20-24.

http://www.ncbi.nlm.nih.gov/pubmed/16056021 http://dx.doi.org/10.1097/00003086-200508000-00005

[2] Gendron, R., Grenier, D. and Maheu-Robert, L. (2000) The Oral Cavity as a Reservoir of Bacterial Pathogens for Focal Infections. Microbes and Infection, 2, 897-906. http://dx.doi.org/10.1016/S1286-4579(00)00391-9

[3] Caufield, P.W. (2000) Dental Caries. An Infectious and Transmissible Disease. Pediatric Clinics of North America, 47, 1001-1019. http://www.ncbi.nlm.nih.gov/pubmed/11059347 http://dx.doi.org/10.1016/S0031-3955(05)70255-8

[4] Leonardo, M.R., Rossi, M.A., Silva, L.A., Ito., I.Y. and Bonifácio, K.C. (2002) EM Evaluation of bacterial Biofilm and Microorganisms on the Apical External Root Surface of Human Teeth. Journal of Endodontics, 28, 815-818. http://www.ncbi.nlm.nih.gov/pubmed/12489650

[5] Nair, P.N.R. (2000) Apical Periodontitis: A Dynamic Encounter between Root Canal Infection and Host Response. Journal of Periodontology Online, 13, 121-148. http://dx.doi.org/10.1111/j.1600-0757.1997.tb00098.x http://onlinelibrary.wiley.com/doi/10.1111/j.1600-0757.1997.tb00098.x/abstract

[6] Stashenko, P., Teles, R. and D’Souza, R. (1998) Periapical Inflammatory Responses and Their Modulation. Critical Reviews in Oral Biology \& Medicine, 9, 498-521. http://www.ncbi.nlm.nih.gov/pubmed/9825224 http://dx.doi.org/10.1177/10454411980090040701

[7] Cohen, S. and Burns, R.C. (2002) Pathways of the pulp. CV Mosby, St. Louis.

[8] Bergenholtz, G., Hørsted-Bindslev, P. and Reit, C. (2003) Textbook of Endodontology. Blackwell/Munksgaard, Oxford.

[9] Tronstad, L., Barnett, F. and Cervone, F. (1990) Periapical Bacterial Plaque in Teeth Refractory to Endodontic Treatment. Endodontics \& dental traumatology Journal, 6, 73-77. http://www.ncbi.nlm.nih.gov/pubmed/2132213 http://dx.doi.org/10.1111/j.1600-9657.1990.tb00394.x

[10] Kiryu, T., Hoshino, E. and Iwaku, M. (1994) Bacteria Invading Periapical Cementum. Journal of Endodontics, 20, 169-172. http://www.ncbi.nlm.nih.gov/pubmed/8035155 http://dx.doi.org/10.1016/S0099-2399(06)80328-6

[11] Lomcali, G., Sen, B.H. and Cankaya, H. (1996) Scanning Electron Microscopic Observations of Apical Root Surfaces of Teeth with Apical Periodontitis. Dental Traumatology, 12, 70-76. http://www.ncbi.nlm.nih.gov/pubmed/9028200 http://dx.doi.org/10.1111/j.1600-9657.1996.tb00100.x

[12] Seow, W.K. (2003) Diagnosis and Management of Unusual Abscess in Children. Australian Dental Journal, 48, 156168. http://www.ncbi.nlm.nih.gov/pubmed/14640368

[13] Gray, M.M., Marchment, M.D. and Anderson, R.J. (1991) The Relationship between Caries Experience in the Deciduous Molars at 5 Years and in First Permanent Molars of the Same Child at 7 Years. Community Dental Health, 8, 3-7. http://www.ncbi.nlm.nih.gov/pubmed/2049653

[14] Caste, L.M., Selwitz, R.H., Oldakowski, R.J., Brunelle, J.A., Winn, D.M. and Brrown, L.J. (1996) Coronal Caries in the Primary and Permanent Dentition of Children and Adolescents 1-17 Years of Age: United States, 1988-1991. Journal of Dental Research, 75, 631-641. http://www.ncbi.nlm.nih.gov/pubmed/8594087

[15] Hunt, D.E., King, T.J. and Fuller, G.E. (1978) Antibiotic Susceptibility of Bacteria Isolated from Oral Infections. Journal of Oral Surgery, 36, 527-529. http://www.ncbi.nlm.nih.gov/pubmed/277637

[16] Heimdahl, A., Von Konow, L., Satoh, T. and Nord, C.E. (1985) Clinical Appearance Orofacial Infections of Odontogenic Origin in Relation of Microbiological Findings. Journal of Clinical Microbiology, 22, 299-302. http://www.ncbi.nlm.nih.gov/pmc/articles/PMC268380/

[17] Batty, I. (1958) Actinomyces odontolyticus, a New Species of Actinomycete Regularly Isolated from Deep Carious Dentine. The Journal of Pathology and Bacteriology, 75, 455-459. http://dx.doi.org/10.1002/path.1700750225 http://onlinelibrary.wiley.com/doi/10.1002/path.1700750225/abstract

[18] Dodson, T.B., Peroth, D.H. and Kaban, L.B. (1989) Pedriatic Maxillofacial Infections: A Retrospective Study of 113 Patients. Journal of Oral and Maxillofacial Surgery, 47, 327-330. http://www.ncbi.nlm.nih.gov/pubmed/2926541

[19] Sunde, P.T., Olsen, I., Lind, P.O. and Tronstad, L. (2000) Extraradicular Infection: A Methodological Study. Dental Traumatology, 16, 84-90. http://www.ncbi.nlm.nih.gov/pubmed/11202862 
http://dx.doi.org/10.1034/j.1600-9657.2000.016002084.x

[20] Sunde, P.T., Tronstad, L., Eribe, E.R., Lind, P.O. and Olsen, I. (2000) Assessment of Periradicular Microbiota by DNADNA Hybridization. Dental Traumatology, 16, 191-196. http://www.ncbi.nlm.nih.gov/pubmed/11202881 http://dx.doi.org/10.1034/j.1600-9657.2000.016005191.x

[21] Gatti, J.J., Dobeck, J.M., Smith, C., White, R.R., Socransky, S.S. and Skobe, Z. (2000) Bacteria of Asymptomatic Periradicular Endodontic Lesions Identified by DNA-DNA Hybridization. Dental Traumatology, 16, 197-204.

http://www.ncbi.nlm.nih.gov/pubmed/11202882 http://dx.doi.org/10.1034/j.1600-9657.2000.016005197.x

[22] Graunaite, I., Lodiene, G. and Maciulskiene, V. (2012) Pathogenesis of Apical Periodontitis: A Literature Review. Journal of Oral and Maxillofacial Surgery, 2, 1011-1023. http://www.ncbi.nlm.nih.gov/pubmed/24421998

[23] Ricucci, D. and Siqueira, J.F. (2010) Biofilms and Apical Periodontitis: Study of Prevalence and Association with Clinical and Histopathologic Findings. Journal of Endodontics, 36, 1277-1288. http://www.ncbi.nlm.nih.gov/pubmed/20647081

[24] Pazelli, L.C., Freitas, A.C., Ito, I.Y., Souza-Gugelmin, M.C.M., Medeiros, A.S. and Nelson-Filho, P. (2003) Prevalence of Microorganisms in Root Canals of Human Deciduous Teeth with Necrotic Pulp and Chronic Periapical Lesions. Pesquisa Odontológica Brasileira, 17, 367-371. http://dx.doi.org/10.1590/S1517-74912003000400013

https://www.google.com/webhp?sourceid=chrome-instant\&rlz=1C1CHMO_enXK560XK560\&ion=1\&espv=2\&ie=UT F-8\#q=prevalence\%20of\%20microorganisms\%20in\%20root\%20canals\%20of\%20human\%20deciduous\%20teeth\%20 with\%20necrotic\%20pulp\%20and\%20chronic\%20periapical\%20lesions

[25] Sakaguchi, M., Sato, S., Ishigama, T., Katsuno, S. and Taguchi, K. (1997) Characteristics and Management of Deep Neck Infections. International Journal of Oral and Maxillofacial Surgery, 26, 131-134.

http://www.ncbi.nlm.nih.gov/pmc/articles/PMC4050086/ http://dx.doi.org/10.1016/S0901-5027(05)80835-5

[26] Oguntebi, B., Slee, A.M., Tanzer, J.M. and Langeland, K. (1982) Predominant Microflora Associated with Human Dental Periapical Abscesses. Journal of Clinical Microbiology, 15, 964-966. http://www.ncbi.nlm.nih.gov/pmc/articles/PMC272224/

[27] Hegde, A.M. and Lakshmi, P.K. (2013) Prevalence of Selected Microorganisms in the Pulp Space of Human Deciduous Teeth with Irreversible Pulpitis. Journal of Endodontology, 25, 107-111. http://medind.nic.in/eaa/t13/i1/eaat13i1p107.pdf

[28] Brook, I., Grimm, S. and Kielich, R.B. (1981) Bacteriology of Acute Periapical Abscess in Children. Journal of Endodontology, 7, 378-380. http://www.jendodon.com/article/S0099-2399\%2881\%2980060-X/abstract

[29] Marsh, S.J. and Largent, M.D. (1967) A Bacteriological Study of the Pulp Canals of Infected Primary Molars. Journal of Dentistry for Children, 34, 460-470. http://www.ncbi.nlm.nih.gov/pubmed/4864179

[30] da Silva, L.A.B., Leonardo, M.R., de Oliveira, D.S.B., da Silva, R.A.B., de Queiroz, A.M., Hernández, P.G. and Nelson-Filho, P. (2010) Histopathological Evaluation of Root Canal Filling Materials for Primary Teeth. Brazilian Dental Journal, 21. http://www.scielo.br/scielo.php?script=sci_arttext\&pid=S0103-64402010000100006

[31] Siqueira, J.F. and Rocas, I.N. (2003) Bacteriodes forsythus in Primary Endodontic Infections as Detected by Nested PCR. Journal of Endodontology, 29, 390-393. http://www.ncbi.nlm.nih.gov/pubmed/12814221 http://dx.doi.org/10.1097/00004770-200306000-00002

[32] Gill, Y. and Scully, C. (1990) Orofacial Odontogenic Infections: Review of Microbiology and Current Treatment. Oral Surgery, Oral Medicine, Oral Pathology, 70, 155-158. http://www.ncbi.nlm.nih.gov/pubmed/2290641 http://dx.doi.org/10.1016/0030-4220(90)90109-6

[33] Rani, A. and Chopra, A. (2006) Isolation and Identification of Root Canal Bacteria from Symptomatic Nonvital Teeth with Periapical Pathosis. Endodontology, 18, 12-17. http://medind.nic.in/eaa/t06/i1/eaat06i1p12.pdf 